\begin{tabular}{|c|c|c|c|c|}
\hline JURNAL & \multirow{2}{*}{ VOLUME 2 } & NOMOR 2 & HALAMAN 157-163 & $\begin{array}{c}\text { ISSN 2655-8823 }(p) \\
\text { ISSN 2656-1786 }(e)\end{array}$ \\
KOLABORASI RESOLUSI KONFLIK & H
\end{tabular}

\title{
KEGIATAN RELAKSASI SEBAGAI COPING STRESS DI MASA PANDEMI COVID-19
}

\author{
Alma Fildzah Aufar \\ Program Studi Ilmu Kesejahteraan Sosial, FISIP Universitas Padjadjaran \\ E-mail: $\underline{\text { alma18001@mail.unpad.ac.id }}$ \\ Santoso Tri Raharjo \\ Pusat Studi CSR, Kewirausahaan Sosial, dan Pemberdayaan Masyarakat, FISIP Universitas Padjadjaran \\ E-mail: santoso.tri.raharjo@unpad.ac.id
}

\begin{abstract}
ABSTRAK
Fenomena Corona Virus Disease (COVID-19) menjadi sebuah bencana multidimensional yang terjadi di berbagai negara termasuk Indonesia. Pandemi ini bukan hanya berdampak pada sektor-sektor utama seperti kesehatan dan perekonomian tetapi juga dalam interaksi sosal kehidupan masyarakat yang menuntut adanya proses adaptasi pada upaya pencegahan penularan virus seperti social distancing atau physical distancing. Selain mengacu pada protokol kesehatan, namun hal itu tidak lah cukup, dibutuhkan adaptasi dalam merespon perubahan yang besar ini agar mampu menghadapi permasalahan kesehatan fisik dan mental di masyarakat. Salah satu cara yang dapat menghilangkan kecemasan atau stress yang dialami masyarakat dalam praktik pekerjaan sosial dengan inidividu yaitu relaksasi. Aktivitas relaksasi pada era teknologi tidak hanya dapat dilakukan melalui metode secara langsung tetapi juga telah hadir dalam berbagai platform digital di tengah masyarakat. Hal ini juga didukung dengan media-media berita elektronik yang turut merekomendasikan kegiatan relaksasi. Artikel ini mencoba untuk menggambarkan dan menjelaskan efektifitas metode relaksasi sebagai alternatif mengatasi stres selama pandemi Covid-19. Sehingga relaksasi dapat dijadikan sebagai alternatif teknik sosial yang mendukung proses adaptasi individu dan kelompok, serta komunitas.
\end{abstract}

Kata kunci: Covid-19, Adaptasi, Relaksasi, Coping Stress.

\section{PENDAHULUAN}

Dunia sedang mengalami masa yang berat sejak awal tahun 2020 ini karena dikejutkan dengan adanya fenomena Corona Virus Disease atau COVID-19. Berbagai negara termasuk Indonesia masih berjuang untuk mengatasi virus ini, karena dampaknya bukan hanya terjadi pada sektor kesehatan tetapi juga berbagai sektor lainnya (multidimensional) seperti perekonomian, pendidikan, juga interaksi sosial yang terjadi di masyarakat. Portal berita Tirto.id mencatat bahwa pada tanggal 5 Juni 2020, total kasus positif Corona di Indonesia mencapai 29.521 pasien, sedangkan tertinggi di dunia yaitu Amerika Serikat mencapai 1.872.660 dan diperkirakan akan terus meningkat setiap harinya (tirto.id, 2020).

Dalam merespon fenomena ini, Indonesia mengeluarkan beberapa kebijakan terutama dalam mengatur interaksi sosial masyarakatnya untuk mencegah angka penyebaran virus semakin tinggi. Mulai dari anjuran melakukan Social Distancing atau Physical Distancing hingga kebijakan resmi seperti Pembatasan Sosial Berskala Besar (PSBB) yang ditetapkan oleh pemerintah daerah. Kebijakan dan anjuran yang dilakukan pemerintah ini memberikan dampak yang cukup besar bagi kehidupan sosial masyarakat di Indonesia.

Memudarnya interaksi sosial antara lain dapat dirasakan dari aktivitas-aktivitas yang dilakukan secara massal di ruang publik merujuk pada Peraturan Menteri Kesehatan Nomor 9 Tahun 2020 tentang Pedoman Pembatasan Sosial Berskala Besar (PSBB) dalam Rangka Percepatan Penanganan Covid-19 pasal 13 (Kemenkes RI, 2020) seperti:

1. Peliburan sekolah dan tempat kerja. Aktivitas pendidikan yang dilaksanakan langsung di ruang 


\begin{tabular}{|c|c|c|c|c|}
\hline JURNAL & \multirow{2}{*}{ VOLUME 2 } & NOMOR 2 & HALAMAN 157-163 & $\begin{array}{l}\text { ISSN 2655-8823 }(p) \\
\text { ISSN 2656-1786 }(e)\end{array}$ \\
\hline KOLABORASI RESOLUSI KONFLIK & HALS \\
\hline
\end{tabular}

kelas diganti dengan pembelajaran berbasis daring di rumah berdasarkan Surat Edaran Kemdikbud No 4 Tahun 2020 mengenai Pelaksanaan Pendidikan Dalam Masa Darurat Coronavirus Disease (Covid-19) (Mendikbud RI, 2020). Sedangkan aktivitas di dalam suatu lingkungan pekerjaan diberlakukan anjuran work from home dan dikecualikan untuk beberapa kantor atau instansi pokok.

2. Aktivitas keagamaan dilakukan di rumah dan dihadiri keluarga terbatas, dengan menjaga jarak setiap orang. Majelis Ulama Indonsia (MUI) juga mengeluarkan fatwa Nomor 31 Tahun 2020 Tentang Penyelenggaraan Salat Jumat dan Jamaah untuk mencegah penularan Covid-19.

3. Aktivitas di tempat dan fasilitas umum yang dibatasi dengan pembatasan jumlah orang dan juga pengaturan jarak.

4. Aktivitas atau kegiatan sosial dan budaya.

5. Aktivitas mobilisasi menggunakan moda transportasi.

Semua aktivitas atau kegiatan yang tidak mendesak dianjurkan untuk dilakukan seminimal mungkin dalam lingkungan luar rumah dengan tetap wajib melaksanakan protokol kesehatan. Hal ini dapat mempengaruhi interaksi di masyarakat yang sebelumnya bersifat langsung (tatap muka pada satu tempat satu waktu) sedangkan pada masa pandemi ini dibutuhkannya adaptasi seperti melakukan interaksi dari rumah masingmasing dengan memanfaatkan teknologi.

Pandemi Covid-19 bukan hanya mengancam atau berpengaruh pada kesehatan fisik masyarakat tetapi juga pada kesehatan jiwa. Adaptasi terhadap perubahan yang terjadi dalam menjalani aktivitas keseharian "yang baru" bukan merupakan hal yang mudah. Kesulitan menghadapi perubahan ini dapat meningkatkan stress. Selain itu, Melihat dan mengetahui data statistik penyebaran virus dan jumlah pasien positif hingga jumlah korban dunia dapat menyebabkan tingkat kecemasan bertambah.

Sebagai contoh, hasil penelitian dalam jurnal Psychiatry Research mensurvei lebih dari 7.200 pria dan wanita si China selama lockdown yang diberlakukan pada Februari di negara itu. Lebih dari sepertiga ditemukan menderita "gangguan kecemasan umum" terkait-COVID, sementara sekitar seperlima berjuang dengan adanya tanda-tanda depresi. Sedangkan lebih dari 18\% mengatakan adanya aktivitas kesulitan untuk tidur (Huang \& Zhao, 2020).

Selain itu, tak dapat dipungkiri bahwa keadaan atau situasi yang dihadapi setiap harinya berbeda dari sebelum terjadinya pandemi ini. Semua orang mungkin mengalami kesulitan tetapi kesulitan tersebut dapat berbeda-beda pada setiap orangnya.

Beban kerja ganda yang dialami orang dewasa saat bekerja di dalam rumah yaitu antara pekerjaan yang dilakukan di rumah dengan pekerjaan rumah itu sendiri, bahkan sampai pada kesulitan-kesulitan lainnya seperti kesulitan ekonomi akibat pekerjaan maupun penghasilan. Selain itu, pelajar yang menggunakan metode pembelajaran jarak jauh juga tidak sepernuhnya menyenangkan bagi sebagian orang karena juga dibatasainya interaksi secara langsung dengan orang lain. Adaptasi pada keadaan saat ini seperti dapat berpengaruh pada kesehatan mental masyarakat seperti kecemasan berlebih (anxiety) maupun stres.

Teori mengenai stress terus berkembang setiap jamannya, namun secara fundamental, teori stress dibangun dalam 3 pendekatan (Bartlett, 1998; Lyon, 2012; Lumban Gaol, 2016).:

1. Stres model stimulus (rangsangan), dengan kata lain stress ini merujuk pada hal-hal yang diterima langsung oleh individu tanpa adanya penilaian (Staal, 2004). 


\begin{tabular}{|c|c|c|c|c|}
\hline JURNAL & \multirow{2}{*}{ VOLUME 2 } & NOMOR 2 & HALAMAN 157-163 & $\begin{array}{l}\text { ISSN 2655-8823 }(p) \\
\text { ISSN 2656-1786 }(e)\end{array}$ \\
\hline KOLABORASI RESOLUSI KONFLIK & H
\end{tabular}

Bartlett (1998) menegaskan bahwa stres ini lebih fokus pada sumber stres dari pada sumber lainnya. Sumber stress (stressor) dikategorikan berdasarkan tiga jenis yaitu (1) life events (peristiwa kehidupan) adalah perubahan besar yang memerlukan perilaku adaptasi dalam periode waktu yang relative singkat (misalnya kelahiran anak pertama, perceraian), (2) chronic strain (ketegangan kronis) merupakan tuntutan yang berulang juga membutuhkan penyesuaian kembali dalam waktu lama (misalnya melumpuhkan cidera, kemiskinan, masalah perkawinan), dan (3) daily hassles (permasalahan-permasalahan

sehari-hari) yang merujuk kepada peristiwa kecil yang memerlukan penyesuaian perilaku kecil selama waktu yang singkat (misalnya kemacetan lalu lintas, pengunjung tak terduga, makan enak) (Thoits, 1995).

2. Stres model response (respon), Selye (1950) mendefisinikan stress ini sebagai hasil inividu merespon stimulus yang diberikan atau reaksi tanggapan tubuh terhadap penyebab stress yang mempengaruhi seseorang. Contoh stres ini apabila seseorang merasakan keadaan yang mengkhawatirkan, ancaman yang muncul kemudian direspon spontan oleh tubuh. Ancaman merupakan sumber stres, respon tubuh merupakan stres respon (Scheneidrman, Ironson \& Siegel, 2005; Lumban Gaol, 2016).

3. Stres model transactional (transaksional) yaitu sebagai penilaian dari individu terhadap suatu penyebab stres yang kemudian akan menentukan respon individu tersebut (Lumban Gaol, 2016; Staal, 2004). Berdasarkan adanya tuntutan-tuntutan yang timbul terhadap kondisi kesehatan, individu secara khusus menilai atau mengevaluasinya (Lyon, 2012).

Gejala kecemasan yang muncul dari dampak kondisi pandemi ini juga dapat menyebabkan stres berlebih yang dikhawatirkan dapat menganggu keberfungsian sosial seseorang dalam menjalani aktivitasnya sehari-hari. Untuk mengatasi gejala-gejala yang muncul pada kesehatan jiwa yang muncul di masa pandemic ini diperlukannya treatment khusus yang dilakukan baik secara individu, keluarga, maupun kelompok. Proses ini biasanya disebut dengan kegiatan coping stress. Coping adalah keadaan atau kondisi seseorang yang megalami stres dan membutuhkan kemampuan pribadi maupun dukungan dari lingkungan untuk melalui hal tersebut (Rasmun, 2004). Salah satu coping stress yang dapat dilakukan semasa pandemi ini yaitu relaksasi. Maka artikel ini bertujuan untuk melihat sejauh mana efektifitas kegiatan relaksasi dalam masa pandemi Covid-19.

Studi pustaka dan didukung berbagai data sekunder dari WHO, serta berbagai sumber atau situs terkait dengan tujuan dari kajian ini.

\section{PEMBAHASAN}

Salah satu metode yang dapat dilakukan oleh seorang pekerja sosial dalam melakukan praktik konseling terhadap klien individu, keluarga, kelompok yaitu dengan melakukan relaksasi. Relaksasi adalah suatu kegiatan melemaskan otot-otot pada tubuh yang berguna untuk mengurangi ketegangan yang dirasakan oleh tubuh (Sari \& Murtini).

Manfaat yang dapat dirasakan setelah melakukan proses relaksasi antara lain menurut (Utami, 2001) yaitu:

1. Membantu seseorang lebih mampu menghindari melakukan hal-hal yang berlebihan akibat dari stress.

2. Berkurangnya masalah yang timbul akibat stres seperti akit kepala, 
tekanan darah tinggi, insomnia dan perilaku buruk lainnya.

3. Mengurangi kecemasan dan menunjukan efek psikologis yang positif pada seseorang.

4. Meningkatkan semangat dalam menjalankan aktivitas.

5. Meningkatkan hubungan interpersonal.

Proses kegiatan relaksasi ini berpegang kuat pada pengaturan pernapasan serta sugesti agar dapat merasakan ketenangan dan menghilangkan kecemasan. Agar klien merasakan rileks di seluruh tubuhnya dari ujung kepala hingga ujung kaki, aktivitas relaksasi ini dilakukan dengan memberikan sugesti kepada klien. Selain itu, klien juga dituntun untuk dapat mengistirahatkan pikirannya dan merasakan kenyamanan, damai, bahagia atau perasaan positif lainnya pada dirinya (Budi, 2010). Maka selanjutnya tantangan dalam keberhasilan dari kegiatan relasasi untuk menghilangkan kecemasan bahkan stres semasa pandemi ini adalah penyampaian sugesti yang kuat agar dapat diterima dengan baik oleh klien atau siapapun yang melaksanakan kegiatan tersebut.

Kegiatan relaksasi awalya merupakan kegiatan yang dipandu dan dilakukan secara langsung kepada seorang klien tetapi semakin berkembangnya zaman, paa masa dan era digital ini sudah banyak platform atau media yang memudahkan orang mengakses dan melakukan relaksasi secara individu maupun kelompok dalam satu lokasi yang sama. Bahkan, Ikatan Psikolog Klinis Indonesia menyediakan Audio Panduan Relaksasi Meredakan Stres Pikiran dan Tubuh dalam rangka dukungan psikologis kepada masyarakat Indonesia untuk mengatasi kecemasan dalam menghadapi masa pandemic Covid-19 (Ikatan Psikolog Klinis Indonesia, 2020).

Selain itu, konsep relaksasi dalam platform digital ini sudah banyak hadir salah satunya dalam kanal Youtube dengan menggunakan audiovisual yang memandu penonton dalam melakukan relaksasi lengkap dengan ilustrasi, sugesti juga membantu secara pendengaran yang seakan-akan berada dalam situasi yang nyaman. Selain itu salah satu media music player yang popular di masyarakat di Indonesia yaitu bahkan menambahkan kategori relaxation (relaksasi) apabila pendengarnya menjelajahi halaman Wellness. Kategori ini merujuk pada playlist yang kemudian menyuguhkan pendengarnya dengan berbagai podcast maupun audio yang membuat keadaan diri bisa lebih relaks.

Gugus Tugas Percepatan Penanganan Covid-19 di Indonesia juga melihat permasalahan kesehatan mental yang dapat ditimbulkan pada masa pandemic ini menjadi perhatian bagi mereka. Dilansir dari portal media covid19.go.id, Perwakilan Perhimpunan Dokter Spesialis Kedokteran Jiwa Indonesia dr. Lahargo Kembaren, Sp.KJ Jumat (1/5/2020) menyampaikan beberapa tips dalam mengatasi gejala kesehaan jiwa seperti membatasi dalam memperoleh informasi melalui media, memilah informasi yang diperoleh, juga melakukan hal positif. Selain itu, beliau juga menyarankan untuk berkonsultasi dengan professional kesehatan jiwa dan melakukan teknik keterampilan seperti relaksasi.

Kementerian Kesehatan Republik Indoenesia juga membuat poster menarik sebagai salah satu bentuk Gerakan Masyarakat Sehat (Germas) dengan tagar Kelola Stres. Poster digital ini berbicara mengenai teknik relaksas untuk mengatasi stres yang dapat dilakukan dengan cara yang mudah yaitu melalui 3 langkah: (1) Menginstruksikan untuk duduk dengan posisi yang dianggap dapat membuat nyaman dan santai (dalam ilustrasi duduk bersila) juga mata terpejam sekaligus membayangkan hal yang menyenangkan, (2) Menginstruksikan untuk menerapkan rasa bersyukur terhadap nikmat yang telah diberikan oleh Tuhan YME serta sikap ikhlas dan sabar, (3) Menginstruksikan untuk menarik nafas dari hidung kemudian menahannya dalam 3 hitungan dan 


\begin{tabular}{|c|c|c|c|c|}
\hline JURNAL & \multirow{2}{*}{ VOLUME 2 } & NOMOR 2 & HALAMAN 157-163 & $\begin{array}{l}\text { ISSN 2655-8823 }(p) \\
\text { ISSN 2656-1786 }(e)\end{array}$ \\
KOLABORASI RESOLUSI KONFLIK & HAM \\
\hline
\end{tabular}

selanjutnya menghembuskan nafas melalui mulut serta sambal membayangkan seolah beban yang ada sudah dilepaskan. Poster ini juga telah tersebar di berbagai media online Direktorat Pencegahan dan Penanganan dan Pengendalian Penyakit Tidak Menular Kementerian Kesehatan Republik Indonesia (Drektorat Pencegahan dan Pengendalian Penyakit Tidak Menular, 2018)

Bukan hanya itu tetapi dari hasil survey yang dilakukan mengenai kebutuhan kesehatan jiwa bagi tenaga kesehatan di RSCM pada 393 orang partisipan, mengatakan sebanyak $42.2 \%$ responden tenaga kesehatan menyatakan bahwa dirinya memerlukan layanan kesehatan jiwa akibat tekanan pekerjaan yang dilakukan selama ini di rumah sakit semasa pandemi. (L Redayani, 2020). Dalam mengintervensi kebutuhan akan layanan, intervensi psikoterapi yang diberikan salah satunya juga merujuk kepada proses relaksasi yaitu mengatur nafas, merilekskan otot-otot, membayangkan tempat nyaman dan tenang juga menyebutkan kalimat pendukung pribadi yang bermakna positif seperti "Saat ini saya akan selalu tenang, rileks dan sehat" (L Redayani, 2020)

Kecenderungan orang mengakses media berita pada saat pandemi ini juga lebih besar sebagai upaya untuk terus mendapatkan informasi. Dari berbagai portal berita yang ada juga turut merekomendasikan kegiatan relaksasi ini untuk dilakukan dalam pencegahan atau kegiatan mengatasi kecenderungan kecemasan bahkan stres selama pandemi seperti:

1. CNN Indonesia yang memberitakan seputar cara relaksasi untuk meredam kecemasan. Dalam artikel berita ini disajikan informasi mengenai caracara relakasasi yang dapat dilakukan di dalam rumah mengutip dari situs psikologi Help Guide yaitu menggunakan pernapasan dalam, relaksasi otot progresif, visualisasi, meditasi mindfulness, gerakan berirama, juga yang terakhir melakukan kegiatan olahraga Yoga yang mengombinasikan serangkaian pose dan juga menggunakan pernapasan dalam (CNN Indonesia, 2020)

2. Halodoc, yaitu sebuah media kesehatan yang memberikan sarana bagi masyarakat untuk mengakses informasi seputar kesehatan dan juga konseling memberikan suatu artikel berita mengenai metode sofrologi dalam relaksasi yang efektif untuk tubuh. Dalam artikel ini dijelaskan bahwa sofrologi merupakan meditasi dinamis yang melibakan pikiran, tubuh juga mendorong interaksi antara belahan otak kanan dan kiri. Metode sofrologi juga melibatkan banyak aspek dalam tubuh seperti relaksasi, pernapasan, meditasi, gerakan tubuh yang lembut juga visualiasasi. Manfaat dari sofrologi juga dapat dirasakan seperti tidur menjadi nyenyak, melepaskan ketegangan dan juga mengendalikan napas (halodoc, 2020).

3. Lifestyle Kompas, dalam media berita ini juga membahas teknikteknik relaksasi apa saja yang dapat dilakukan untuk mengatasi stres seperti relaksasi otot progresif (sumber berdasarkan pendiri Plum Counseling and Wellness, Jessie Bohnenkamp, LPC, NCC), ambil nafas dalam dan berjalan (sumber berdasarkan pendiri of Hammond Psychology \& Associates, P.A, Nekeshia Hammond, PsyD), hubungi orang tercinta (sumber berdasarkan konselor Louis LavesWebb, LCSW, LPC-S), melakukan pemindaian tubuh spesialis manajemen stres (Sumber berdasarkan Sandra Thébaud, $\mathrm{PhD}$ ), rileks dan kembali 


\begin{tabular}{|c|c|c|c|c|}
\hline JURNAL & \multirow{2}{*}{ VOLUME 2 } & NOMOR 2 & HALAMAN 157-163 & $\begin{array}{l}\text { ISSN 2655-8823 }(p) \\
\text { ISSN 2656-1786 }(e)\end{array}$ \\
KOLABORASI RESOLUSI KONFLIK & HAM \\
\hline
\end{tabular}

meremajakan diri pendiri (Sumber berdasarkan Wellness IRL, Tasha Holland-Kornegay, $\mathrm{PhD}$, LPC), melakukan peregangan (Sumber berdasarkan Dr. HollandKornegay), olahraga, berbicara kepada diri sendiri (Sumber berdasarkan Direktur laboratorium psikofisiologi Michigan State University, Jason Moser, $\mathrm{PhD}$ ) Meditasi (sumber berdasarkan Dr. Moser) (Lifestyle Kompas, 2020).

Ketiga berita tersebut mewakili beritaberita lainnya yang juga turut merekomendasikan kegiatan relaksasi sebagai salah satu kegiatan positif yang dapat dilakukan dalam upaya mengurangi stres masa pandemi ini juga menjaga kesehatan mental masyarakat.

\section{KESIMPULAN DAN SARAN}

Dengan adanya berbagai media yang mendukung informasi terkait pentingnya menjaga kesehatan bukan hanya fisik tetapi juga mental pada masa pandemi Covid-19 ini juga khususnya pengedukasian lebih terkait dengan salah satu teknik yang dapat dilakukan yaitu relaksasi diharapkan dapat membuat kondisi yang baru ini dapat dijalani dengan lebih baik lagi. Tetapi masih disayangkan bahwa belum adanya penelitian yang mengkaji secara lebih jelas terkait seberapa efektif dan berpengaruh teknikteknik mengatasi kecemasan juga stres ini dalam kondisi Covid-19 pada orang-orang yang terkena dampaknya. Semoga penelitian yang dilakukan selanjutnya dapat bersifat lebih komprehensif.

\section{DAFTAR PUSTAKA}

Budi, P. P. (2010). Cara Cepat Menguasai Hypnohealing. Yogyakarta: Leutika.

CNN Indonesia. (2020, Maret 24). 6 Cara Relaksasi untuk Redam Kcemasan. Retrieved from CNN Indonesia: https://www.cnnindonesia.com/gayahidup/20200324104821-255486350/6-cara-relaksasi-untuk-redamkecemasan

\section{DIREKTORAT PENCEGAHAN DAN PENGENDALIAN PENYAKIT}

TIDAK MENULAR. (2018, Desember 16). Teknik relaksasi untuk mengatasi stres. Retrieved from Kementerian Kesehatan Republik Indonesia: http://p2ptm.kemkes.go.id/infographic$\mathrm{p} 2 \mathrm{ptm} /$ stress/teknik-relaksasi-untukmengatasi-stres

Gugus Tugas Percepatan Penanganan Covid-19. (2020, May 1). Tips Kesehatan Jiwa Menghadapi Situasi Dampak Pandemi COVID-19. Retrieved from Covid 19: https://covid19.go.id/p/berita/tipskesehatan-jiwa-menghadapi-situasidampak-pandemi-covid-19

halodoc. (2020, Maret 28). Kenalan dengan Sofrologi, Metode Relaksasi yang Menenangkan. Retrieved from halodoc:

https://www.halodoc.com/kenalandengan-sofrologi-metode-relaksasiyang-menenangkan

Huang, Y., \& Zhao, N. (2020). Generalized anxiety disorder, depressive symptoms and sleep quality during COVID-19 outbreak in China: a web-based cross-sectional survey. Psychiatry Research, 288(March), 112954.

https://doi.org/10.1016/j.psychres.2020 .112954

Ikatan Psikolog Klinis Indonesia. (2020, Maret 26). AUDIO PANDUAN RELAKSASI MEREDAKAN STRES PIKIRAN DAN TUBUH DI MASA PANDEMI COVID-19. Retrieved from IPK Indonesia: https://ipkindonesia.or.id/psikoedukasi -covid19/2020/03/psikoedukasi-covid-

Kemenkes RI. (2020). Peraturan Menteri Kesehatan Republik Indonesia Nomor 9 Tahun 2020 Tentang Pedoman Pembatasan Sosial Berskala Besar Dalam Rangka Percepatan Penanganan Corona Virus Disease 2019 (Covid19). Kementerian Kesehatan RI, 28. http://hukor.kemkes.go.id/uploads/pro duk_hukum/PMK_No_99_Th_2020_tt 


\begin{tabular}{|c|c|c|c|c|}
\hline JURNAL & \multirow{2}{*}{ VOLUME 2 } & NOMOR 2 & HALAMAN 157-163 & $\begin{array}{c}\text { ISSN 2655-8823 }(p) \\
\text { ISSN 2656-1786 }(e)\end{array}$ \\
KOLABORASI RESOLUSI KONFLIK & HOMS
\end{tabular}

g_Pedoman_Pembatasan_Sosial_Bersk ala_Besar_Dalam_Penanganan_COVI D-19.pdf

L Redayani, P. (2020). Dampak Covid terhadap Kesehatan Mental Nakes: April.

Lifestyle Kompas. (2020, April 7). 9 Teknik Relaksasi untuk Atasi Stres. Retrieved from Lifestyle Kompas: https://lifestyle.kompas.com/read/2020 /04/07/085413220/9-teknik-relaksasiuntuk-atasi-stres?page $=$ all

Lumban Gaol, N. T. (2016). Teori Stres: Stimulus, Respons, dan Transaksional. Buletin Psikologi, 24(1), 1. https://doi.org/10.22146/bpsi.11224

Lyon, B. L. (2012). Handbook of stress, coping and health: Implications for nursing research, theory, and practice. US: Sage Publication, Inc.

Mendikbud RI. (2020). Surat Edaran Nomor 4 Tahun 2020 Tentang Pelaksanaan Kebijakan Pendidikan Dalam Masa Darurat Penyebaran
Coronavirus Disease (COVID-19). 13. https://www.kemdikbud.go.id/

Rasmun. (2004). Stres, Koping dan Adaptasi. Jakarta: Sagung Seto.

Sari, H. F., \& Murtini. (n.d.). RELAKSASI UNTUK MENGURANGI STRES PADA PENDERITA HIPERTENSI ESENSIAL. HUMANITAS, 14.

Staal, M. A. (2004). Stress, cognition and human performance. August.

Thoits, P. A. (1995). Stress, coping, and social support processes: where are we? What next? Journal of Health and Social Behavior, Spec No(1995), 5379. https://doi.org/10.2307/2626957

tirto.id. (2020, Juni 5). Update Corona Hari Ini di Indonesia \& Dunia: Data Baru 5 Juni 2020. Retrieved from tirto.id: https://tirto.id/update-coronahari-ini-di-indonesia-dunia-data-baru5-juni-2020-fFoY 